Research article

\title{
Elevated serum immunoglobulin E to Cryptomeria japonica pollen in rats exposed to diesel exhaust during fetal and neonatal periods Nobue Watanabe* and Masanobu Ohsawa
}

\author{
Address: Department of Environmental Health, Tokyo Metropolitan Research Laboratory of Public Health, Tokyo, Japan \\ E-mail: Nobue Watanabe* - nobuew@tokyo-eiken.go.jp; Masanobu Ohsawa - osawa@tokyo-eiken.go.jp \\ ${ }^{*}$ Corresponding author
}

Received: 31 January 2002

BMC Pregnancy and Childbirth 2002, 2:2

Accepted: 25 March 2002

This article is available from: http://www.biomedcentral.com/I47I-2393/2/2

(c) 2002 Watanabe and Ohsawa; licensee BioMed Central Ltd. Verbatim copying and redistribution of this article are permitted in any medium for any purpose, provided this notice is preserved along with the article's original URL.

\begin{abstract}
Background: The possible participation of diesel exhaust inhalation during the fetal period in the elevation of lgE against pollen in postnatal life was investigated.

Method: The experiment was conducted using rat pups. Group I; exposed to clean air (Control). Group 2, 3; exposed to total or filtered diesel exhaust during the fetal period (Total-C-C, Filtered-CC). Group 4, 5; exposed to total or filtered diesel exhaust during the suckling period (C-Total-C, CFiltered-C). Group 6,7; exposed to total or filtered diesel exhaust during the weaning period (C-CTotal, C-C-Filtered). Total diesel engine exhaust contained $1.73 \mathrm{mg} / \mathrm{m}^{3}$ particulate matter and 0.79 Ppm nitrogen dioxide; filtered exhaust contained the same gases as the total exhaust without particulate matter. Intraperitoneal injection of $5 \mathrm{mg}$ crude cedar pollen was performed at 2-week intervals from the 49th day after birth.

Results: The mean IgE titers measured by the P-K reaction in the Control, Total-C-C, Filtered-C-C, CTotal-C, C-Filtered-C, C-C-Total and C-C-Filtered were $64.0 \pm 2.7,469.5 \pm 1.6,332.0 \pm 1.7,380.4 \pm 1.7$, $394.8 \pm 1.7,115.9 \pm 1.3$ and $57.0 \pm 2.8$ respectively after the fourth immunization. There were significant differences between Total-C-C, Filtered-C-C, C-Total-C, C-Filtered-C and Control $(p<0.0$ I, $P$ $<0.01, p<0.05, p<0.01$, respectively). The mean IgE titers by ELISA were $0.47 \pm 0.06,0.79 \pm 0.35$, $0.86 \pm 0.46,0.80 \pm 0.22,0.56 \pm 0.08,0.46 \pm 0.04$ and $0.45 \pm 0.03$, respectively. IgE titers in Filtered$C-C$ and $C$-Total- $C$ were significantly higher than in Control ( $P<0.05$ for each).
\end{abstract}

Conclusions: Inhalation of diesel exhaust during differentiation of the immune system accelerated the elevation of IgE against pollen.

\section{Background}

During the last 30 years, the incidence of allergic diseases, including pollen allergy and allergic asthma, has increased in industrialized countries [1-7]. Epidemiological studies suggest that the increase in the prevalence of allergic diseases may be associated with environmental exposures, lifestyle, temporal development of the immune system, and genetics [8]. Diesel exhaust, which is one of the major sources of environmental pollution in the 20th century, has been suspected to accelerate pollen allergy and allergic respiratory diseases [9-12], because diesel exhaust particles (DEP) may act as an adjuvant [13-22] or directly induce activated mast cells to degranulate [23].

Previous studies addressed the possibility that inhalation of diesel exhaust during pregnancy disrupted differentia- 
tion of the thymus in the fetus due to the accumulation of testosterone [24,25]. Testosterone-binding cells have been found in the thymus of 18-day-old fetuses and testosterone can influence the function of specific thymic epithelial cells [26-28]. Such immunodeficiency of the thymus, especially of suppressor T cells, elevates serum immunoglobulin E [29-32]. These findings strongly suggest that the inhalation of diesel exhaust during the differentiation periods suppresses proliferation of the thymus cells and contributes to the development of allergies in postnatal life.

This study was conducted to pursue three objectives. First, we sought to determine the impact that diesel exhaust inhalation during the differentiation periods of the immune system had upon the elevation of immunoglobulin $\mathrm{E}$ against Japanese cedar pollen. To show this, time of exposure to diesel exhaust was based on the developmental process of the thymus $[33,34]$. The second objective was to determine which substances - particulate matter or the gaseous phase present in diesel exhaust - are responsible for the elevation of IgE. The third objective was to determine the mechanism by which the inhalation exerts its toxicity by measuring the serum levels of hormones.

\section{Materials and methods Generation of diesel exhaust}

Diesel engine exhaust was generated by running a $309 \mathrm{cc}$ engine (Model NFAD50, Yanmar Diesel Co., Osaka, Japan) at 2,400 rpm. Exhaust was diluted with clean air in a dilution tunnel and then drawn into the inhalation chamber (particulate matter $=1.73 \mathrm{mg} / \mathrm{m}^{3}$, nitrogen dioxide $=$ $0.79 \mathrm{ppm}$ ). For the filtered group, most of the diesel soot particles in whole exhaust were removed by HEPA filtration (ATM 3QA, Nippon Muki Co., Tokyo, Japan). After filtration, $99.9998 \%$ of particles measuring $0.05 \mu \mathrm{m}$ or more were eliminated. Ventilation was maintained by 15 air exchanges per hour. Concentrations of nitrogen dioxide and nitrogen monoxide were continuously monitored with a chemiluminescent analyzer (Model 8440, Monitor Labs Co., San Diego, CA). Gravimetric measurements of the particulate matter were conducted daily using an automatic beta-ray dust-mass monitor (Model BAM-102, Shibata Scientific Technology Co., Tokyo, Japan). Measurement of particle sizes with a particle fractionating sampler (Andersen Type low pressure impactor LP-20, Tokyo Dylec Co., Tokyo, Japan) confirmed that more than $90 \%$ of the particulate matter in the diesel exhaust measured less than $0.05 \mu \mathrm{m}$.

\section{Experiment I}

\section{Animals and treatments}

Forty-three pregnant Fischer rats (F344/DuCrj) obtained from Charles River Japan (Kanagawa, Japan) were divided into seven groups on the sixth days of pregnancy. The ex- periment was conducted using only male pups from those mothers. Group 1 was exposed to clean air during all of the experimental period (Control). Group 2 was exposed to total diesel exhaust from the 7th day of gestation (day of impregnation = day 0) until 3 days after birth, then exposed to clean air until days 49,82 and 96 after birth. (Total-C-C). Group 3 was exposed to filtered exhaust from the 7 th day of gestation until 3 days after birth, then exposed to clean air until days 49,82 and 96 after birth (Filtered-CC). Group 4 was exposed to diesel exhaust from the 4th day after birth through the 22nd day after birth. The group was exposed to clean air during the other periods of the experiment $(C$-Total-C). Group 5 was exposed to filtered exhaust from the 4 th day after birth through the 22nd day after birth. The group was exposed to clean air during the other periods of the experiment (C-Filtered-C). Group 6 was exposed to diesel exhaust from day 23 after birth until day 41 . The group was exposed to clean air during the other periods of the experiment (C-C-Total). Group 7 was exposed to filtered exhaust from day 23 after birth until day 41. The group was exposed to clean air during the other periods of the experiment (C-C-Filtered). Each group had the same exposure period, 19 days, to diesel exhaust. The number of pregnant rats for groups 1, 2, 3, 4, 5, 6 and 7 were $7,7,7,6,6,5$ and 5 , respectively. Litter sizes ranged from 6 to 11. The total number of pups (male: female) of each group from the mothers were 53 (28:25), 50 (24:26), 54 (25:29), 47 (22:25), 44 (23:21), 43 (22:21) and 45 (20:25), respectively. The experimental protocol is summarized in Figure 1.

Each group of animals was maintained in an inhalation chamber $\left(1.6 \mathrm{~m}^{3}\right)$ at $24 \pm 2^{\circ} \mathrm{C}$ and $55 \pm 5 \%$ humidity on a 12-hr light: 12-hr dark illumination schedule. The diet was standard rat chow containing $1.03 \%$ calcium, $0.70 \%$ phosphorus and $200 \mathrm{IU}$ vitamin D3/100 g (MF, Oriental Yeast Co. Ltd, Tokyo, Japan). The pups were kept with their mothers until weaned at 22 days of age. At the same time, the young rats were divided into groups of males and females?" the male rats were randomly assigned to groups of 6 to 8 housed in a single cage. All the animals were allowed free access to food and water. Exposure to diesel exhaust was 6 h daily from 10 a.m. to 4 p.m., for 19 days.

Body weights, thymus and spleen weights were measured and blood samples were collected to measure the titer of immunoglogulin from the abdominal aorta under ether anesthesia on day 49 before immunization and five days after the 3rd or 4th immunization.

\section{Allergens and immunization procedure}

The crude Japanese cedar pollen allergens were kindly provided by Dr. Maejima through the Japan Automobile Research Institute (Tsukuba, Japan). The amount of pro- 


\section{Immunization}

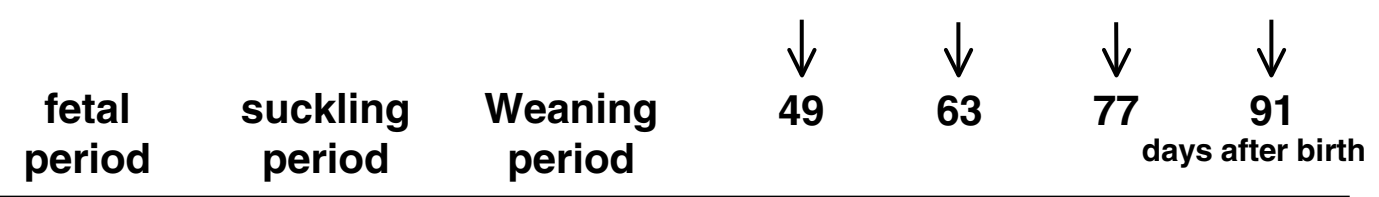

\section{Groups}

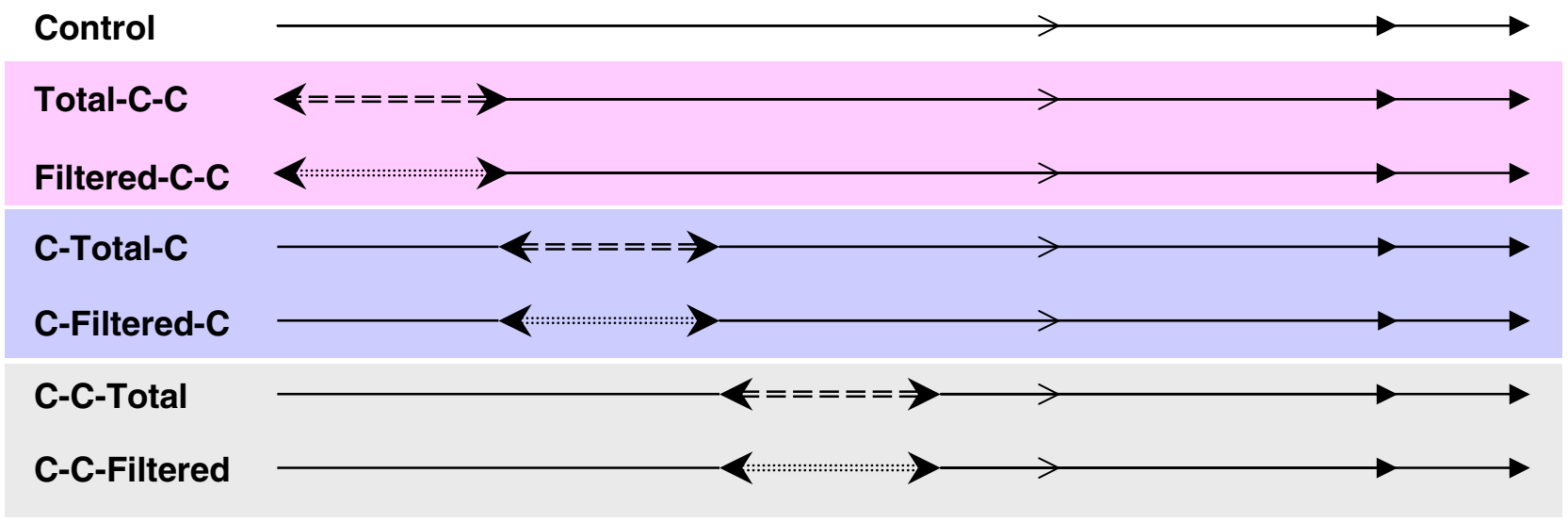

Figure I

Experimental protocol. Control, exposed to clean air; Total-C-C, exposed to total diesel exhaust from the 7th day of gestation until 3 days after birth; Filtered-C-C, exposed to filtered exhaust from the 7th days of gestation until 3 days after birth; $C$-Total- $C$, exposed to diesel exhaust from the 4th day after birth through the 22nd day after birth; C-Filtered-C, exposed to filtered exhaust from the 4th day after birth through the 22 nd day after birth; C-C-Total, exposed to diesel exhaust from day 23 after birth to day 4 I; C-C-Filtered, exposed to filtered exhaust from day 23 after birth to day 4 I.

tein in the crude Japanese cedar pollen allergens was $65 \mu \mathrm{g}$ containing $17.4 \mu \mathrm{g}$ of Cry j 1 and $1.73 \mu \mathrm{g}$ of Cry j 2 per milliliter [35]. Intraperitoneal injection of $1 \mathrm{ml}$ of 0.125 $\mathrm{M}$ ammonium bicarbonate containing $5 \mathrm{mg}$ crude Japanese cedar pollen allergens mixed with $4 \mathrm{mg}$ aluminum hydroxide gel was performed three or four times at 2-week intervals from the 49th day after birth.

Measurement of anti-Japanese cedar pollen IgE antibody titers The titers of IgE antibodies were measured by the Prausnitz-Kustner reaction ( $\mathrm{P}-\mathrm{K}$ reaction) in 12-week-old male Fischer rats (F344/DuCrj) obtained from Charles River Japan (Kanagawa, Japan). One tenth milliliter of serial twofold dilutions of the test sera was injected intracutaneously for the passive sensitization. Forty-eight hours later, the rats were challenged intracutaneously with $0.5 \mu \mathrm{g}$ of Cry $j$ 1 (Hayashibara Biochemical Lab. Inc. Japan) and $0.25 \mu \mathrm{g}$ of Cry j 2 (Hayashibara Biochemical Lab. Inc. Japan) in $0.02 \mathrm{ml}$ of PBS. At the same time, $1 \mathrm{ml}$ of $0.5 \%$ Evans blue was injected intravenously. The test was carried out in duplicate, and the P-K titer was expressed as the geometric means of the reciprocal of the maximal dilutions that elicited a reaction of $5 \mathrm{~mm}$ in diameter.
Enzyme-linked immunosorbent assay (ELISA) of anti-Japanese Cedar Pollen IgE antibodies was carried out by a modification of the method of Imaoka et al. [36]. Briefly, the wells of microtiter plates (Immulon 2, Dynatech) were coated with $100 \mu \mathrm{g} / \mathrm{ml}$ of a commercial anti-rat IgE mouse monoclonal antibody (Zymed, USA) diluted to $20 \mu \mathrm{g} / \mathrm{mL}$ with $0.1 \mathrm{M} \mathrm{NaHCO}_{3}$ (pH8.2) at $37^{\circ} \mathrm{C}$ for $3 \mathrm{~h}$, and the plates were washed 5 times with phosphate buffered saline (PBS). The wells were then successively incubated at room temperature with the following reagents, washing 5 times between each pair of steps: $250 \mu \mathrm{L}$ of Block Ace (Dainihon Seiyaku, Osaka, Japan) for blocking at $4{ }^{\circ} \mathrm{C}$ overnight; $100 \mu \mathrm{L}$ of serial 10 -fold dilutions of the test and normal sera?" $100 \mu \mathrm{L}$ of biotinylated cedar pollen allergens (Biotin Labeled Cry j 1 and 2, Hayashibara Biochemical Lab. Inc. Japan $)(1 \mu \mathrm{g} / \mathrm{mL}) ; 100 \mu \mathrm{L}$ of streptavidin-peroxidase (Zymed, USA) diluted 1:1,000; $100 \mu \mathrm{L}$ of substrate solution containing 3, 3', 5, 5'-tetramethylbenzidine (Morinaga, Japan). Absorbance was read at $450 \mathrm{~nm}$ with a microplate reader. IgE titers were expressed as the absorbance obtained by subtracting the absorbance of the serum from control group. 


\section{Experiment 2}

Eighteen pregnant Fischer rats were divided into three groups: control, total exposed and filtered exposed. The exposure period was from day 7 of pregnancy until 3 days after delivery, corresponding to Control, Total-C-C and Filtered-C-C in experiment 1 . On day 4 after birth, blood samples of newborn rats were collected. The serum pooled from the male pups of the same group was used as a sample. Serum testosterone and estradiol levels were determined using Enzyme Immunoassay Kits (Cayman Chemical, USA). Exposure conditions were the same as aforementioned.

Suckling rats with their mothers were divided into three groups on day 4 after birth: control, total exposed and filtered exposed, corresponding to Control, C-Total- $C$ and $C$ Filtered-C in experiment 1 . The number of mother rats was six. On day 23 after birth, blood samples of weaned males were collected and hormonal levels were assayed.

\section{Statistical analysis}

All reported values are expressed as means \pm standard deviations (SD) or means \pm standard errors (SE) except for testosterone and estradiol of 4-day-old rats in experiment 2. The differences between the groups were analyzed using the Dunnett's test and Steel's test. The rank-order correlation between IgE titers was measured by ELISA and those of the P-K reaction were analyzed by Spearman's method. P-values $<0.05$ were considered significant.

The treatment and care of the rats were carried out according to the protocol approved by the Animal Care and Use Committee of the Tokyo Metropolitan Research Laboratory of Public Health in a facility approved by the Japan Association for Accreditation of Laboratory Animal Care.

\section{Results \\ Experiment I}

The average body weight, spleen and thymus weight of male rats from 7 groups, Control, Total-C-C, Filtered-C-C, C-Total-C, C-Filtered-C, C-C-Total and C-C-Filtered, on days 49, 82 and 96 are shown in Table 1. The average weight of the thymus of non-immunized rats on day 49 was significantly lower in Total-C-C, Filtered-C-C and CFiltered-C than in the control group $(\mathrm{p}<0.01, \mathrm{p}<0.01, \mathrm{p}$ $<0.05$, respectively). There were no differences in thymus weight between the total-exhaust-exposed group and filtered-exhaust-exposed group. The average weight of the thymus of rats on day 82 after the third immunization was significantly lower in Total-C-C and Filtered-C-C than in the control group ( $\mathrm{p}<0.01, \mathrm{p}<0.05$, respectively). The average weight of the thymus of rats on day 96 after the fourth immunization was significantly lower in Filtered$\mathrm{C}-\mathrm{C}$ and C-Filtered-C than in the control group ( $\mathrm{p}<0.05$ for each). There were no significant differences in thymus weight between the total-exhaust-exposed group and filtered-exhaust-exposed group.

The individual anti-Japanese cedar pollen IgE antibody titer measured by the Prausnitz-Kustner reaction (P-K reaction) and the mean IgE titers in Control, Total-C-C, Filtered-C-C. C-Total-C, C-Filtered-C, C-C-Total and C-CFiltered after the third and fourth immunization are shown in Figure 2. The geometrical means of IgE titers in Control, Total-C-C, Filtered-C-C, C-Total-C, C-Filtered-C, C-C-Total and C-C-Filtered were $32.0 \pm 6.9,181.0 \pm 1.5,166.0 \pm$ $1.4,49.4 \pm 4.0,43.1 \pm 6.5,4.0 \pm 1.0$ and $6.3 \pm 2.0$ after the third immunization, and $64.0 \pm 2.7,469.5 \pm 1.6,332.0 \pm$ $1.7,380.4 \pm 1.7,394.8 \pm 1.7,115.9 \pm 1.3$ and $57.0 \pm 2.8$ after the fourth immunization, respectively. $\log _{2} \mathrm{P}-\mathrm{K}$ IgE titers of each group are shown in Table 3 . There were significant differences between Total-C-C, Filtered-C-C, C-Total-C, C-Filtered-C and Control after the fourth immunization $(\mathrm{p}<0.01, \mathrm{p}<0.01, \mathrm{p}<0.05$, $\mathrm{p}<0.01$, respectively). There were no differences between the totalexposure and filtered-exposure conditions.

The average IgE titers measured by ELISA after the fourth immunization and expressed as optical density in Control, Total-C-C, Filtered-C-C, C-Total-C, C-Filtered-C, C-C-Total and $C$-C-Filtered were $0.47 \pm 0.06,0.79 \pm 0.35,0.86 \pm 0.46$, $0.80 \pm 0.22,0.56 \pm 0.08,0.46 \pm 0.04$ and $0.45 \pm 0.03$, respectively. The IgE titers in Filtered-C-C and C-Total- $C$ were significantly higher than in Control ( $\mathrm{p}<0.05, \mathrm{P}<0.05$, respectively). There was a significant rank-order correlation between the IgE titers measured by ELISA and those of the $\mathrm{P}-\mathrm{K}$ reaction $(\mathrm{p}<0.01)$.

\section{Experiment 2}

Table 2 shows the average body weight, spleen and thymus weight, as well as the serum levels of testosterone and estrogen of 4-day-old males exposed to clean air or diesel exhaust from the 7 th day of gestation to 3 days after birth. The average spleen and thymus weights were significantly lower in Total-C-C $(\mathrm{p}<0.05, \mathrm{p}<0.05)$ and Filtered-C-C $(\mathrm{p}<0.01, \mathrm{P}<0.01)$ than in Control. The testosterone levels were higher in Total-C-C and Filtered-C-C than in Control. Table 2 also shows the average body weight, spleen and thymus weight and hormone levels of 23-day-old male rats exposed to clean air or diesel exhaust during the suckling period. The average thymus weight was significantly lower in C-Filtered-C than in Control ( $\mathrm{p}<0.05)$. The testosterone levels were significantly higher in C-Total-C and C-Filtered-C than in Control $(\mathrm{p}<0.05, \mathrm{P}<0.01$, respectively). There were no significant differences between the total-exhaust-exposed group and filtered-exhaust-exposed group. 
Table I: Average body, spleen and thymus weight of male rats from each group on days 49, 82 and 96

\begin{tabular}{|c|c|c|c|c|c|c|c|c|c|c|c|c|}
\hline & \multicolumn{4}{|c|}{ non-immunized: rats on day 49} & \multicolumn{4}{|c|}{ 82-day-old rats immunized three times } & \multirow[b]{2}{*}{$\begin{array}{l}\text { No. } \\
\text { of } \\
\text { rats }\end{array}$} & \multicolumn{3}{|c|}{ 96-day-old rats immunized four times } \\
\hline & $\begin{array}{l}\text { No } \\
\text { of } \\
\text { rats }\end{array}$ & $\begin{array}{l}\text { body weight } \\
(\mathrm{g})\end{array}$ & spleen (mg) & thymus (mg) & $\begin{array}{l}\text { No } \\
\text { of } \\
\text { rats }\end{array}$ & $\begin{array}{l}\text { body weight } \\
\text { (g) }\end{array}$ & spleen (mg) & thymus (mg) & & $\begin{array}{l}\text { body weight } \\
(\mathrm{g})\end{array}$ & spleen (mg) & thymus (mg) \\
\hline Control & 8 & $143.5 \pm 10.5$ & $488.0 \pm 20.5$ & $323.1 \pm 25.5$ & 8 & $238.7 \pm 5.7$ & $601.8 \pm 28.3$ & $235.0 \pm 19.8$ & 8 & $252.9 \pm 13.4$ & $625.0 \pm 42.0$ & $204.8 \pm 18.6$ \\
\hline Total-C-C & 8 & $143.5 \pm 11.3$ & $488.0 \pm 38.3$ & $276.5 \pm 18.9^{*}$ & 8 & $230.1 \pm 9.3$ & $601.0 \pm 30.6$ & 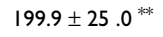 & 8 & $257.6 \pm 17.8$ & $631.8 \pm 41.7$ & $186.5 \pm 20.3$ \\
\hline Filtcred-C-C & 8 & $132.7 \pm 11.9$ & $464.1 \pm 61.5$ & $272.9 \pm 49.3 *$ & 8 & $230.9 \pm 11.5$ & $588.2 \pm 25.0$ & $213.5 \pm 26.7$ & 8 & $249.9 \pm 12.8$ & $658.5 \pm 30.4$ & $179.6 \pm 21.9$ \\
\hline C-Total-C & 8 & $136.1 \pm 7.9$ & $462.0 \pm 30.9$ & $308.2 \pm 26.1$ & 8 & $230.6 \pm 8.5$ & $575.1 \pm 49.4$ & $214.7 \pm 36.6$ & 6 & $256.8 \pm 14.6$ & $619.2 \pm 44.3$ & $210.5 \pm 40.8$ \\
\hline C-Filtcred-C & 7 & $137.8 \pm 7.1$ & $475.0 \pm 25.8$ & $289.0 \pm 23.5$ & 7 & $232.5 \pm 6.5$ & $606.1 \pm 32.5$ & $214.5 \pm 25.1$ & 8 & $241.0 \pm 17.0$ & $608.5 \pm 44.5$ & $176.1 \pm 13.7 *$ \\
\hline C-C-Total & 8 & $146.9 \pm 6.4$ & $488.7 \pm 25.7$ & $310.1 \pm 17.8$ & 7 & $239.7 \pm 10.5$ & $621.9 \pm 14.7$ & $243.1 \pm 23.3$ & 7 & $261.6 \pm 11.5$ & $648.8 \pm 39.1$ & $218.4 \pm 24.2$ \\
\hline C-C-Filtcred & 8 & $142.7 \pm 11.7$ & $490.2 \pm 32.9$ & $309.3 \pm 19.9$ & 6 & $240.2 \pm 9.5$ & $620.0 \pm 21.2$ & $248.2 \pm 19.5$ & 6 & $260.3 \pm 10.1$ & $663.1 \pm 69.6$ & $220.6 \pm 16.0$ \\
\hline
\end{tabular}

Values are expressed as mean $\pm S D$. *Different from Control, $\mathrm{p}<0.05 ;{ }^{* *}$ different from Control, $\mathrm{p}<0.0 \mathrm{I}$

Table 2: Organ weight and serum hormone levels of 4- and 23-day-old male rats from each group.

\begin{tabular}{|c|c|c|c|c|c|c|}
\hline & No. & body weight (g) & spleen (mg) & thymus (mg) & testosterone $(\mathrm{pg} / \mathrm{ml})$ & estrogen $(\mathrm{pg} / \mathrm{ml})$ \\
\hline \multicolumn{7}{|l|}{ 4-day-old rats } \\
\hline Control & 20 & $10.14 \pm 1.11$ & $51.4 \pm 0.1$ & $24.1 \pm 1.1$ & 166.6 & 17.8 \\
\hline Total-C-C & 24 & $9.90 \pm 0.68$ & $46.3 \pm 1.0^{*}$ & $20.4 \pm 1.4^{*}$ & 390.1 & 28.9 \\
\hline Filtered-C-C & 25 & $9.55 \pm 0.86$ & $42.1 \pm 4.3^{* *}$ & $19.0 \pm 1.5^{* *}$ & 255.8 & 16.0 \\
\hline \multicolumn{7}{|l|}{ 23-day-old rats } \\
\hline Control & 10 & $32.35 \pm 2.33$ & $134.1 \pm 16.1$ & $108.4 \pm 17.4$ & $361.1 \pm 139.4$ & $39.8 \pm 19.8$ \\
\hline C-Total-C & 11 & $34.25 \pm 3.61$ & $144.5 \pm 15.2$ & $105.5 \pm 15.1$ & $497.4 \pm 220.6 *$ & $40.4 \pm 26.8$ \\
\hline C-Filtered-C & 8 & $32.84 \pm 5.12$ & $127.1 \pm 20.1$ & $93.2 \pm 17.3^{*}$ & $659.5 \pm 356.2^{* *}$ & $52.5 \pm 22.4$ \\
\hline
\end{tabular}

Values are expressed as mean $\pm S D$. Testosterone and estrogen levels on day 4 were pooled serum from males. ${ }^{*}$ Different from Control, $p<0.05$;

** different from Control, $\mathrm{p}<0.01$

Table 3: IgE titers measured by $\mathrm{P}-\mathrm{K}$ reaction against pollen in rats immunized three or four times

\begin{tabular}{|c|c|c|c|c|}
\hline & \multicolumn{2}{|c|}{ Immunized three times } & \multicolumn{2}{|c|}{ Immunized four times } \\
\hline & $\mathrm{n}$ & $\log _{2} P-K \lg E$ titers & $\mathrm{n}$ & $\log _{2} \mathrm{P}-\mathrm{K} \lg \mathrm{E}$ titers \\
\hline Control & 8 & $5.0 \pm 1.0$ & 8 & $6.0 \pm 0.5$ \\
\hline Total-C-C & 8 & $7.5 \pm 0.2$ & 9 & $8.9 \pm 0.2^{* *}$ \\
\hline Filtered-C-C & 8 & $7.4 \pm 0.2$ & 8 & $8.4 \pm 0.3^{* *}$ \\
\hline C-Total-C & 8 & $5.6 \pm 0.7$ & 6 & $8.6 \pm 0.3^{*}$ \\
\hline C-Filtered-C & 7 & $5.4 \pm 1.0$ & 8 & $8.6 \pm 0.3^{* *}$ \\
\hline C-C-Total & 7 & $2.0 \pm 0.0$ & 7 & $6.9 \pm 0.1$ \\
\hline C-C-Filtered & 6 & $2.7 \pm 0.4$ & 6 & $5.8 \pm 0.6$ \\
\hline
\end{tabular}

Values are expressed as mean \pm SD. Testosterone and estrogen levels on day 4 were pooled serum from males. * Different from Control, $\mathrm{p}<0.05$;

** different from Control, $\mathrm{p}<0.01$ 


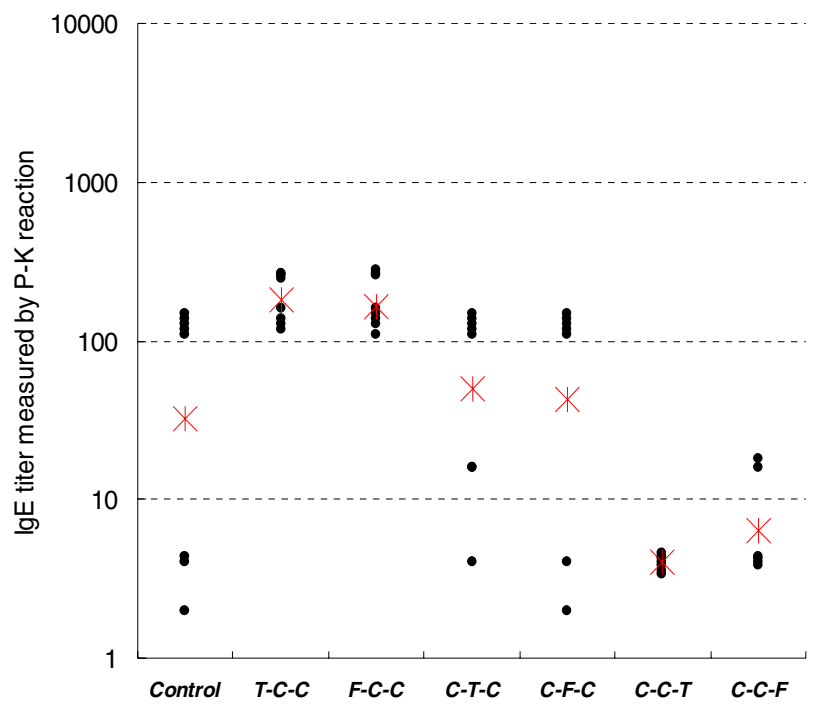

Immunized 3 times

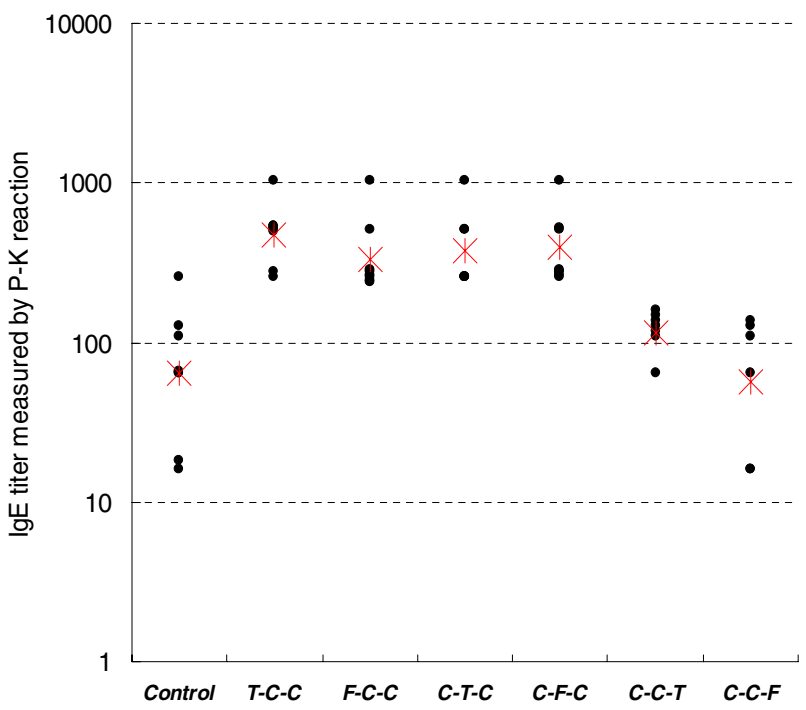

Immunized 4 times

\section{Figure 2}

Anti-Japanese cedar pollen IgE titers measured by $\mathrm{P}-\mathrm{K}$ reaction. $\bullet \lg \mathrm{E}$ titers in the individual rat; ${ }^{*}$ geometrical means of each group

\section{Discussion}

The present study provides the first evidence that inhalation of diesel exhaust during the differentiation periods of the immune system accelerated the elevation of immunoglobulin E (IgE) against Japanese cedar pollen.

Elevation of IgE against Japanese pollen was detected in the rats exposed to total or filtered diesel exhaust from the 7 th day of gestation until 3 days after birth (Total-C-C, Filtered-C-C). Previous studies addressed the possibility that inhalation of diesel exhaust during pregnancy disrupted the differentiation of the thymus in the fetus due to the accumulation of testosterone $[24,25]$. In the present study, the testosterone levels, which were probably closely related to maternal hormone levels, were significantly higher in 4-day-old rats from Total-C-C and Filtered-C-C than the rats from Control. Testosterone-binding cells have been found in the thymus of 18-day-old fetuses. Testosterone can influence the function of specific thymic epithelial cells not only directly by acting on the thymus cells, but also indirectly by modulating the function of the thymus epithelial cells that bind testosterone [26-28,37]. Other possibilities for the depletion of lymphoid cells are a reduction in the rate of bone marrow-derived prothymocyte entry into the thymus [12,38-42], or a higher incidence of thymocyte apotosis $[12,43-45]$. Since a certain number of lymphocytes in the spleen are from the thymus, decreased weight of the spleen on day 4 after birth in $T-C-C$ and $F-C$ -
$C$ might reflect disturbed or delayed development of the thymus. With regard to adjuvant effects of particles, _particles deposited in the maternal organs might have acted as an adjuvant during the fetal and suckling periods and affected immune functions. There is a little possibility that diesel exhaust acted directly as an adjuvant for causing the elevation of IgE. The rats from the groups of Total$C-C$ and Filtered-C-C had been exposed to diesel exhaust through breathing for 3 days.

Elevated IgE was also detected in the rats exposed to diesel exhaust directly during the suckling period, C-Total-C and $C$-Filtered-C. Those rats had been exposed to diesel exhaust in two ways, through inhaled air and mother's milk. It has been indicated that inhalation of nitrogen dioxide, a strong oxidative gas contained in diesel exhaust, reduces T lymphocyte subpopulations [46-48]. The other possibility for hypersensitivity to pollen is the elevated steroid hormone level detected in 23-day-old rats from C-Total-C and $C$-Filtered-C. The influences from deposited particles in the maternal organs could not be neglected. The rats exposed to exhaust directly during weaning period, $C-C-T o$ tal and C-C-Filtered, did not show an elevation of IgE, though those rats had a shorter interval between exposure and the first immunization compared to the rats from the other groups. Holladay et al. suggested [34] that developmental exposure to immunotoxicants may play a role in inducing or exacerbating hypersensitivity, which is long- 
lasting or permanent. It is reasonable to assume that inhalation could have influenced the differentiation period of the thymus, such as the initiation of hematopoiesis, migration of stem cells, the expansion of progenitor cells and the colonization of bone marrow and maturation to immunocompetence and induced hypersensitivity in later life.

The rats from Total-C-C and Filtered-C-C responded to a smaller dose of pollen than the rats from C-Total- $C$ and $C$ Filtered-C. Judging from the decreased weight of the thymus and spleen on day 4 after birth, the impact of diesel exhaust inhalation on the development of the fetal immune system could be stronger than that on the neonatal immune system. Recently, it has been pointed out that the incidence of Japanese cedar pollinosis has increased not only in children but also in infants $[49,50]$. There could be some connection between insufficient development of immune system during the fetal and neonatal periods because the mother has been exposed to polluted air and the increased prevalence of Japanese cedar pollinosis and atopic diseases in infants.

Regarding which substances were more responsible for insufficient development of the immune system and elevation of IgE, filtered-exhaust that included the gaseous phase and ultra fine particles measuring less than $0.05 \mu \mathrm{m}$ might be responsible. Although the two exposure conditions, total-exhaust-exposure and filtered-exhaust-exposure had almost the same affect, the latter had a more severe impact on pups. When comparing pups from fetalperiod-filtered-exposed group (Filtered-C-C) to those of the fetal-period-total-exposed group (Total-C-C), the thymus weights were significantly lower in Filtered-C-C than in the Control on postnatal day 96. In pups from the suckling-period-exposed group (C-Filtered-C), the thymus weights on days 23, 49 and 96 were lower than those in the Control. There were no significant differences between the thymus weight of Filtered-C-C and Total-C-C. Filtered exhaust contained the remainder of diesel exhaust after filtration, such as gases and particles measuring less than $0.05 \mu \mathrm{m}$. The gaseous phase of diesel engine exhaust includes several agents that may affect immune functions, such as nitrogen dioxide and nitrogen oxide [46-48]. Recently the toxicity of ultrafine particles less than $0.1 \mu \mathrm{m}$ has been reported, such as the direct invasion of ultrafine particles through the lung, the translocation of deposited ultrafine particles to extrapulmonary tissues, the impact of co-pollutants adsorbed to ultrafine particles [52-54]. It can not be negligible that ultrafine particles transferred from the mother to the fetus or inhaled act as immunotoxicants. Further studies are needed to show the mechanism that is responsible for susceptibility to allergies in rats exposed to diesel exhaust during the critical period of immune system development.
The yearly average suspended particulate matter (SPM) concentration in a specified area at the motor vehicle exhaust monitoring station of motor vehicle NOx during 1999 was $0.045 \mathrm{mg} / \mathrm{m}^{3}[51]$. Assuming the proportion of diesel exhaust particles in SPM around the roads in large cities to be $40 \%$, the concentration of the diesel exhaust particles used in this experiment is about 90 times the concentration occurring around the roads. The rats had been exposed to diesel exhaust for 16 days during their fetal life, which is more than two thirds of the gestation period. Taking the longer gestation period of human beings, a longer time of exposure per day and a larger volume of breathing into consideration, the inhalation dose used in the present study was not far from reality.

The intranasal administration is a more reasonable simulation of the natural route of pollen exposure. It is also useful to estimate the amount of pollen grains being administered. In the preliminary studies, intranasal administration was not useful for elevating IgE in Fischer rats. The major purposes of the study were to show that environmental factors could change the sensibility to pollen besides genetic factors and to show the influence of diesel exhaust inhalation on the fetus and neonate. Antibody responses against Japanese cedar pollen differed among strains of rats, with Brown Norway (BN) rats being sensitive, Fischer rats moderately sensitive and Wistar rats not sensitive [36]. The average litter size in $\mathrm{BN}$ rats is 3 to 4 , and that of Fischer rats is 8 to 10 . For these reasons, intraperitoneal injection was administered in Fischer rats in the present study. Even if alternative routes of pollen grain administration were used, the predictability of such methods generally used in scientific research field is well acceptable to mimic and study human allergic reaction in a rat model.

\section{Competing interests}

none declared

\section{Authors' contributions}

NW designed the study, carried out the immunoassays and drafted the manuscript. $\mathrm{MO}$ carried out the regulation of exposure conditions in the inhalation chambers and participated in the immunoassays. All authors read and approved the final draft.

\section{Acknowledgements}

This work was supported by CREST of JST (Japan Science and Technology Corporation).

\section{References}

I. Austin JB, Kaur B, Anderson HR, Burr M, Harkins LS, Strachan DP Warner JO: Hay fever, eczema, and wheeze: a nationwide UK study (ISAAC, international study of asthma and allergies in childhood). Arch Dis Child 1999, 8 I:225-230

2. Haahtela T, Lindholm H, Bjorksten F, Koskenvuo K, Laitinen LA: Prevalence of asthma in Finnish young men. BMJ 1990, 30 I(6746):266-268 
3. Ninan TK, Russell G: Respiratory symptoms and atopy in Aberdeen schoolchildren: evidence from two surveys 25 years apart. BMJ I992, 304(683 I):873-875

4. Nishihata S, Inouye S, Saiga T, Sahashi N, Suzuki S, Murayama K, Yokoyama T, Saito Y: Prevalence rate of allergy to Japanese cedar pollen in Tokyo-from field investigation in 1996 by Tokyo Japanese Cedar Pollen Allergy Measurements and Review Committee Arerugi 1999, 48:597-604

5. Omran M, Russell G: Continuing increase in respiratory symptoms and atopy in Aberdeen schoolchildren. BMJ 1996, 3 I 2(7022): 34

6. Rusznak C, Bayram H, Devalia JL, Davies RJ: Impact of the environment on allergic lung diseases. Exp. Allergy 1997, Suppl. I:26-35

7. Tanaka A, Iwase A, Tanigaito Y: Epidemiology of Japanese cedar pollinosis: result of the survey in Mibu-machi. Nippon Jibiinkoka Gakkai Kaiho 1999, 102:35-41

8. Kemeny DM: The effects of pollutants on the allergic immune response. Toxicology 2000, I52:3-12

9. Corbo GM, Forastiere F, Dell'Orco V, Pistelli R, Agabiti N, De Stefanis B, Ciappi G, Perucci CA: Effects of environment on atopic status and respiratory disorders in children. J Allergy Clin Immunol 1993, 92:616-623

10. Ishizaki T, Koizumi K, Ikemori R, Ishiyama Y, Kushibiki E: Studies of prevalence of Japanese cedar pollinosis among the residents in a densely cultivated area. Ann. Allergy 1987, 58:265-270

II. Naito K, Iwata S, Yokoyama N: Laryngeal symptoms in patients exposed to Japanese cedar pollen: allergic reactions and environmental pollution. Eur Arch Otorhinolaryngol 1999, 256:209211

12. Peterson B, Saxon A: Global increases in allergic respiratory disease: the possible role of diesel exhaust particles. Ann Allergy Asthma Immunol 1996, 77:263-268

13. Diaz-Sanchez D, Tsien A, Fleming J, Saxon A: Effect of topical fluticasone propionate on the mucosal allergic response induced by ragweed allergen and diesel exhaust particle challenge. Clin Immunol 1999, 90:313-322

14. Diaz-Sanchez D, Garcia MP, Wang M, Jyrala M, Saxon A: Nasal challenge with diesel exhaust particles can induce sensitization to a neoallergen in the human mucosa. J Allergy Clin Immunol 1999, 104:1183-1188

15. Fujimaki H, Saneyoshi K, Shiraishi F, Imai T, Endo T: Inhalation of diesel exhaust enhances antigen-specific IgE antibody production in mice. Toxicology 1997, I 16:227-233

16. Granum B, Gaarder PI, Lovik M: IgE adjuvant effect caused by particles - immediate and delayed effects. Toxicology 200I, 156:149-159

17. Lovik M, Hogseth AK, Gaarder PI, Hagemann R, Eide I: Diesel exhaust particles and carbon black have adjuvant activity on the local lymph node response and systemic IgE production to ovalbumin. Toxicology 1997, I 21:165-178

18. Muranaka M, Suzuki S, Koizumi K, Takafuji S, Miyamoto T, Ikemori R, Tokiwa $\mathrm{H}$ : Adjuvant activity of diesel-exhaust particulates for the production of IgE antibody in mice. J Allergy Clin Immunol 1986, 77:616-623

19. Nilsen A, Hagemann R, Eide I: The adjuvant activity of diesel exhaust particles and carbon black on systemic IgE production to ovalbumin in mice after intranasal instillation. Toxicology 1997, I 24:225-232

20. Steerenberg PA, Dormans JA, van Doom CC, Middendorp S, Vos JG, van $\mathrm{H}$ : A pollen model in the rat for testing adjuvant activity of air pollution components. Inhal Toxicol 1999, I I: I 109- I 122

21. Steinsvik TE, Ormstad H, Gaarder PI, Aaberge IS, Bjonness U, Lovik $M$ : Human IgE production in hu-PBL-SCID mice injected with birch pollen and diesel exhaust particles. Toxicology 1998 , 1 28:219-230

22. Takafuji S, Suzuki S, Koizumi K, Tadokoro K, Miyamoto T, Ikemori R, Muranaka M: Diesel-exhaust particulates inoculated by the intranasal route have an adjuvant activity for IgE production in mice. J Allergy Clin Immunol 1987, 79:639-645

23. Diaz-Sanchez D, Penichet-Garcia M, Saxon A: Diesel exhaust particles directly induce activated mast cells to degranulate and increase histamine levels and symptom severity. J Allergy Clin Immunol 2000, 106: I I40-II 46

24. Watanabe N, Ohsawa M, Uehara S: Immunosuppression in rats exposed to diesel exhaust from fetal life. Presented at the Annual
Meeting Japan Society of Endocrine Disrupter Research, 15 December, Yokohama, Japan. 2000

25. Watanabe N, Kurita M: The masculinization of the fetus during pregnancy due to inhalation of diesel exhaust. Environ Health Perspect 2001, 109: III-119

26. Kumar N, Shan LX, Hardy MP, Bardin CW, Sundaram K: Mechanism of androgen-induced thymolysis in rats. Endocrinology 1995, 136:4887-4893

27. Leposavic G, Micic M: Testosterone binding sites in the rat thymus during late embryonal and postnatal period. Thymus 1992, 20:77-88

28. Olsen NJ, Olson G, Viselli S, Gu X, Kovacs XJ: 200I. Androgen receptors in thymic epithelium modulate thymus size and thymocyte development. Endocrinology 200I, I 42:1278-I283

29. Holmes BJ, MacAry PA, Noble A, Kemeny DM: Antigen-specific CD8+ $T$ cells inhibit IgE responses and interleukin-4 production by CD4+ T cells. Eur J Immunol 1997, 27:2657-2665

30. Kemeny DM, Diaz-Sanchez D: Role of CD8 T cells in rat IgE responses. Int Arch Allergy Appi Immunol 1999, 94:99-I0I

31. Kemeny DM, Noble A, Holmes B], Diaz-Sanchez D, Lee TH: The role of $C D 8+T$ cells in immunoglobulin $E$ regulation. Allergy 1995, 50(25 Suppl):9-14

32. Kemeny DM: CD8+ T cells in atopic disease. Curr Opin Immunol $1998,10: 628-633$

33. Dietert RR, Etzel RA, Chen D, Halonen M, Holladay SD, Jarabek AM, Landreth K, Peden DB, Pinkerton K, Smialowicz RJ, Zoetis T: Workshop to Identify Critical Windows of Exposure for Children's Health: Immune and Respiratory Systems Work Group Summary. Environ Health Perspect 2000, 108(suppl 3):483-509

34. Holladay SD, Smialowicz RJ: Development of the Murine and Human Immune System: Differential Effects of Immunotoxicants Depend on Time of Exposure. Environ Health Perspect 2000, 108(suppl 3):463-473

35. Maejima K, Tamura K, Taniguchi Y, Nagase S, Tanaka HH: Comparison of the effects of various fine particles on IgE antibody production in mice inhaling Japanese cedar pollen allergens. J Toxicol Environ Health 1997, 52:23 I-248

36. Imaoka K, Sakaguchi M, Inouye S: Antibody responses against Japanese Cedar pollen allergen (Cry $j \mathrm{l}$ ) in different strains of rats. Jikken Dobutsu 1993, 42:6 I-65

37. Viselli SM, Olsen NJ, Shults K, Steizer G, Kovacs WJ: Immunochemical and flow cytometric analysis of androgen receptor expression in thymocytes. Mol Cell Endocrinol 1995, 109:19-26

38. Masuzawa T, Miyaura C, Onoe Y, Kusano K, Ohta H, Nozawa S, Suda $\mathrm{T}$ : Estrogen deficiency stimulates $\mathrm{B}$ lymphopoiesis in mouse bone marrow. J Clin Invest 1994, 94:1090-1097

39. Medina KL, Kincade PW: Pregnancy-related steroids are potential negative regulators of $B$ lymphopoiesis. Proc Natl Acad Sci U S A 1994, 91 (12):5382-5386

40. Sfikakis PP, Kostomitsopoulos N, Kittas C, Stathopoulos J, Karayannacos P, Dellia-Sfikakis A, Mitropoulos D: Tamoxifen exerts testosterone-dependent and independent effects on thymic involution. Int I Immunopharmacol 1998, 20:305-3 I2

4I. Viselli SM, Reese KR, Fan J, Kovacs WJ, Olsen NJ: Androgens alter B cell development in normal male mice. Cell Immunol 1997. 182:99-104

42. Wilson CA, Mrose SA, Thomas DW: Enhanced production of B lymphocytes after castration. Blood 1995, 85:1535-1539

43. Guevara Patino JA, Marino MW, Ivanov VN, Nikolich-Zugich J: Sex steroids induce apoptosis of CD8+CD4+ double-positive thymocytes via TNF-alpha. Eur J Immiunol 2000, 30:2586-2592

44. McMurray RW, Wilson JG, Bigler L, Xiang L, Lagoo A: Progesterone inhibits glucocorticoid-induced murine thymocyte apoptosis. Int I Immunopharmacol 2000, 22:955-965

45. Olsen NJ, Viselli SM, Fan J, Kovacs WJ: Androgens accelerate thymocyte apoptosis. Endocrinology 1998, 139:748-752

46. Damji KS, Richters A: Reduction in T lymphocyte subpopulations following acute exposure to $4 \mathrm{ppm}$ nitrogen dioxide. Environ Res 1989, 49:217-224

47. Fujimaki H, Shimizu F, Kubota K: Effect of subacute exposure to $\mathrm{NO}_{2}$ on lymphocytes required for antibody responses. Environ Res 1982, 29:280-286

48. Richters A, Damji HS: Changes in T-lymphocyte subpopulations and natural killer cells following exposure to ambient levels of nitrogen dioxide. J Toxicol Environ Health 1988, 25:247-256 
49. Masuda S, Takeuchi K, Yuta A, Okawa C, Ukai K, Sakakura Y: Japanese cedar pollinosis in children in our allergy clinic. Arerugi 1998, 47:1182-1189

50. Masuda S, Terada A, Fujisawa T, Iguchi K: Japanese cedar pollinosis in infants in the allergy clinic. Arerugi 2000, 49:। I38- I I 45

5I. Steams RC, Murthy GGK, Skornik W, Katler M, Goldeski J]: Detection of ultrafine copper oxide particles in the lungs of hamsters by electron spectroscopic imaging. ICEM. 13, Paris, 1994, 17-22

52. Ferin J, Oberdörster G, Penny DP: Pulmonary retention of ultrafine and fine particles in rats. Am J Respir Cell Biol 1992, 6:535542

53. Oberdörster G, Finkelstein JN, Johnston C, Gelein R, Cox C, Baggs $R$, Elder A: Investigator's Report: Acute pulmonary effects of ultrafine particles in rats and mice. The Health Effects Institute Report 96, Cambridge, MA, 2000

54. Sato K: Current state of examination on overall measures against suspended particulate matter. International Symposium on Ambient Fine Particles and Health. 29-40, Tokyo, 1999

\section{Pre-publication history}

The pre-publication history for this paper can be accessed here:

http://www.biomedcentral.com/1471-2393/2/2/prepub

Publish with BioMed Central and every scientist can read your work free of charge

"BioMedcentral will be the most significant development for disseminating the results of biomedical research in our lifetime." Paul Nurse, Director-General, Imperial Cancer Research Fund

Publish with BMC and your research papers will be:

- available free of charge to the entire biomedical community

- peer reviewed and published immediately upon acceptance

- cited in PubMed and archived on PubMed Central

- yours - you keep the copyright 